\title{
Penerapan Algoritma K-Means dalam Pengelompokan Jumlah Penduduk Berdasarkan Kelurahan di Kota Pematangsiantar
}

\author{
Luvita Yolanda Hutabarat ${ }^{1 凶)}$, Indra Gunawan ${ }^{2)}$, Ika Purnamasari ${ }^{3)}$, M Safii ${ }^{4)}$, \\ Widodo Saputra ${ }^{5)}$
}

${ }^{12) 344) 5)}$ Program Studi Teknik Informatika, STIKOM Tunas Bangsa, Pematangsiantar, Indonesia

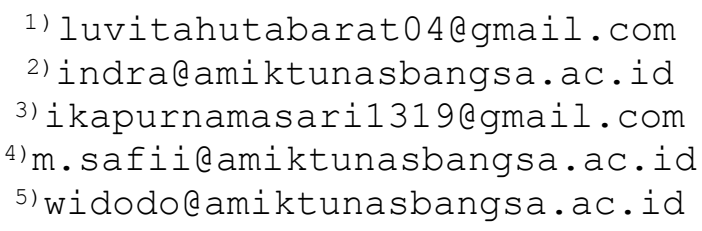

\begin{abstract}
The increase in population in a city or district if not resolved properly and systematically will result in bad impacts. Population growth will affect economic growth and population density. In this study, the population in Pematangsiantar city will be grouped to determine the low, medium and high population so that there is no population density. This study uses data mining techniques using the $\mathrm{K}$ Means Clustering algorithm. This study uses 3 clusters and the results obtained from the calculation of the K-Means algorithm are 29 urban villages with low population clusters, 18 urban villages with moderate population clusters, 6 urban villages with high population clusters.
\end{abstract}

Keywords-Data Mining, K-Means, Clustering, Total Population.

Intisari- Pertambahan jumlah penduduk di suatu kota ataupun kabupaten jika tidak diselesaikan dengan baik dan sistematis akan mengakibatkan dampak-dampak yang buruk. Pertambahan jumlah penduduk akan mempengaruhi pertumbuhan ekonomi dan kepadatan penduduk. Pada penelitian ini akan dilakukan pengelompokan jumlah penduduk di kota Pematangsiantar untuk mengetahui jumlah penduduk yang rendah, sedang dan tinggi agar tidak terjadi kepadatan penduduk. Penelitian ini menggunakan teknik data mining dengan menggunakan algoritma K-Means Clustering. Penelitian ini memakai 3 Cluster dan hasil yang didapatkan dari perhitungan algoritma K-Means adalah Cluster jumlah penduduk rendah sebanyak 29 kelurahan, Cluster jumlah penduduk sedang sebanyak 18 kelurahan, Cluster jumlah penduduk tinggi sebanyak 6 kelurahan.

Kata Kunci-Data Mining, K-Means, Clustering, Jumlah Penduduk.

\section{PENDAHULUAN}

Pada dasarnya penduduk merupakan modal dasar pembangunan, oleh karena itu data statistik kependudukan sepenuhnya diperlukan untuk kepentingan perencanaan pembangunan dengan segala aspeknya. Pertumbuhan penduduk yang tidak seimbang dengan pertumbuhan kesempatan kerja, mengakibatkan meningkatnya jumlah pengangguran. Pertambahan jumlah penduduk di suatu kota ataupun kabupaten jika tidak diselesaikan dengan baik dan sistematis akan mengakibatkan dampak-dampak yang buruk. Pertambahan jumlah penduduk juga akan mempengaruhi pertumbuhan ekonomi dan kesejahteraan rakyat [1].

Dengan banyaknya pertambahan jumlah penduduk di kota Pematangsiantar, diperlukan adanya pengelompokan jumlah penduduk berdasarkan kelurahan sebagai salah satu upaya untuk mencegah kepadatan penduduk dan dampak-dampak buruk lainnya. Oleh karena itu, dibuatlah pengolahan data yang dapat menyelesaikan permasalahan tersebut yaitu menerapkan teknik data mining menggunakan algoritma $K$ Means terhadap data jumlah penduduk berdasarkan kelurahan di kota Pematangsiantar.

K-Means merupakan salah satu metode data Clustering non-hirarki yang berusaha mempartisi data yang ada ke dalam bentuk satu atau lebih Cluster/kelompok. Metode ini mempartisi data ke dalam Cluster/kelompok sehingga data yang memiliki karakteristik sama dikelompokkan ke dalam satu Cluster yang sama [2].

Pada penelitian yang dilakukan oleh Sonang dan tim menggunakan algoritma $K$-Means untuk mengelompokan jumlah penduduk berdasarkan kategori usia. Hasil pengujian yang didapat yaitu kelompok jumlah penduduk tinggi berdasarkan usia ada 3 kecamatan sedangkan kelompok jumlah penduduk rendah berdasarkan usia ada 5 kecamatan [3].

Pada penelitian ini data jumlah penduduk yang digunakan diambil dari Badan Pusat Statistik Pematangsiantar. Data jumlah penduduk yang diperoleh per kelurahan di Kota Pematangsiantar yaitu dari tahun 2015 sampai tahun 2019 yang terdiri dari 53 kelurahan. Data jumlah penduduk yang diperoleh akan dilakukan penelitian dalam mengelompokan jumlah penduduk berdasarkan kelurahan menggunakan 
algoritma K-Means. Pengelompokan dibagi menjadi 3 cluster yaitu cluster jumlah penduduk rendah, cluster jumlah penduduk sedang, dan cluster jumlah penduduk tinggi. Pengelompokan dilakukan untuk menjadi sebuah solusi agar pemerintah memperhatikan kelompok jumlah penduduk untuk mencegah kepadatan penduduk dan dampak-dampak buruk lainnya supaya kesejahteraan masyarakat lebih terjamin.

\section{METODOLOGI}

\section{A. Rancangan Penelitian}

Rancangan penelitian ini yang dilakukan oleh penulis pertama kali yaitu melakukan observasi dan mengumpulkan data langsung dari Badan Pusat Statistik (BPS) kota Pematangsiantar. Data tersebut akan diolah menggunakan algoritma K-Means dan diuji menggunakan RapidMiner untuk mengetahui apakah pengujian RapidMiner sesuai dengan perhitungan manual menggunakan algoritma $K$ Means. Berikut rancangan penelitian dapat dilihat pada gambar 1.

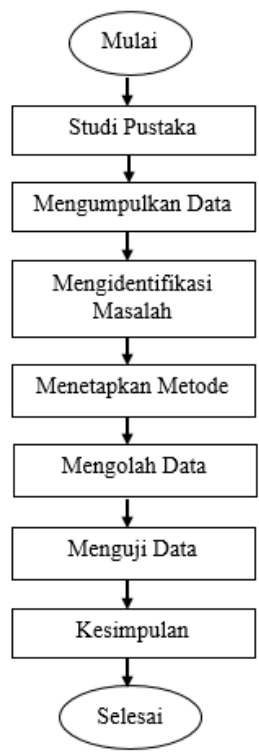

Gambar 1. Rancangan Penelitian

\section{B. Data Mining}

Data Mining adalah proses yang menggunakan teknik statistik, matematika, kecerdasan buatan, dan machinelearning untuk mengektrasi dan mengidentifikasi informasi yang bermanfaat dan pengetahuan yang terkait dari berbagai database besar [4]. Data Mining dibagi menjadi beberapa kelompok berdasarkan tugas yang dapat dilakukan, yaitu[5] :

1. Classification Suatu teknik dengan melihat pada kelakuan dan atribut dari kelompok yang telah didefinisikan. Teknik ini dapat memberikan klasifikasi pada data baru dengan memanipulasi data yang ada yang telah diklasifikasi dan dengan menggunakan hasilnya untuk memberikan sejumlah aturan.

2. Association Digunakan untuk mengenali kelakuan dari kejadian-kejadian khusus atau proses dimana hubungan asosiasi muncul pada setiap kejadian.
3. Clustering Digunakan untuk menganalisis pengelompokkan berbeda terhadap data, mirip dengan klasifikasi, namun pengelompokkan belum didefinisikan sebelum dijalankannya tool data mining.

"Tahapan yang dilakukan pada proses data mining diawali dari seleksi data dari data sumber ke data target, tahap preprocessing untuk memperbaiki kualitas data, transformasi, data mining serta tahap interpretasi dan evaluasi yang menghasilkan output berupa pengetahuan baru yang diharapkan memberikan kontribusi yang lebih baik" [6]. Secara detail dijelaskan sebagai berikut:

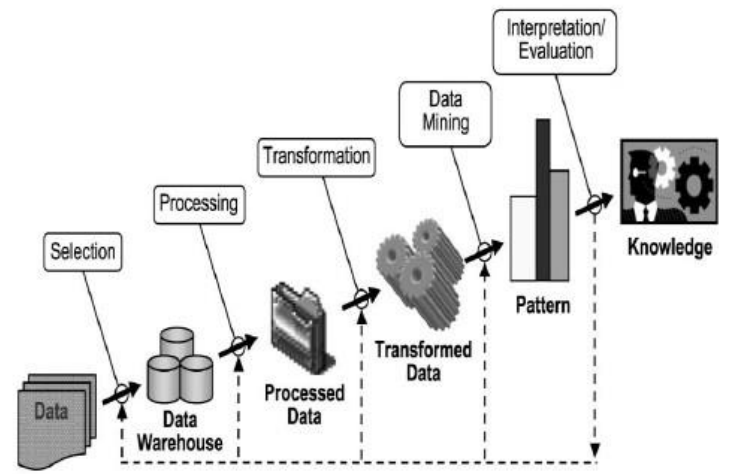

Gambar 2. Tahapan Proses Data Mining

\section{Clustering}

Clustering merupakan salah satu teknik dari salah satu fungsionalitas datamining, algoritma Clustering merupakan pengelompokan sejumlah data menjadi kelompok-kelompok data tertentu (Cluster)[7].

\section{RapidMiner}

RapidMiner merupakan perangkat lunak yang dapat diakses oleh siapa saja dan bersifat terbuka (open source). RapidMiner ini dijadikan sebuah solusi untuk menganalisa terhadap data processing. Pada RapidMiner ini digunakan berbagai teknik seperti teknik deskriptif dan prediksi. RapidMiner ini menggunakan bahasa Java untuk pengoperasian nya [8].

\section{E. Algoritma K-Means}

K-Means merupakan salah satu algoritma Clustering yang masuk dalam kelompok Unsupersived Learning yang digunakan untuk membagi data menjadi beberapa kelompok dengan sistem partisi. Algoritma ini menerima masukan berupa data tanpa label kelas. Pada setiap Cluster terdapat titik pusat (Centroid) yang mempresentasikan Cluster tersebut. Secara sederhana algoritma $K$-Means dapat dijelaskan sebagai algoritma data mining yang digunakan untuk menyelesaikan masalah pengelompokkan (Clustering)[9].

Langkah-langkah melakukan Clustering dengan metode K-Means adalah sebagai berikut [10]:

1. Tentukan jumlah Cluster (k) pada data set

2. Tentukan nilai pusat (Centroid) Penentuan nilai Centroid pada tahap awal dilakukan secara random, 
Hutabarat, Gunawan, Purnamasari, Safii, \& Saputra JURNAL ILMU KOMPUTER DAN TEKNOLOGI Vol. 2, No. 2, Nov 2021, pp. 20-26

sedangkan pada tahap iterasi digunakan rumus seperti berikut ini:

$$
V_{i j}=\frac{1}{N_{i}} \sum_{k=0}^{N_{i}} X_{k j}
$$

Keterangan:

$\mathrm{V}_{\mathrm{ij}}=$ Centroid rata-rata Cluster ke-i untuk variable ke-j

$\mathrm{N}_{\mathrm{i}}=$ Jumlah anggota Cluster ke-i

$\mathrm{i}, \mathrm{k}=$ Indeks dari Cluster

$\mathrm{j}=$ Indeks dari variable

$\mathrm{X}_{\mathrm{kj}}=$ Nilai data ke-k variable ke-j untuk Cluster tersebut

3. Pada masing-masing record, hitung jarak terdekat dengan Centroid. Jarak Centroid yang digunakan adalah Euclidean Distance, dengan rumus seperti berikut ini:

$$
D e=\sqrt{\left(x_{i}-s_{i}\right)^{2}+\left(y_{i}-t_{i}\right)^{2}}
$$

Keterangan:

De = Euclidean Distance

$\mathrm{i}$ = banyaknya objek

$(\mathrm{x}, \mathrm{y})=$ Koordinat objek

$(\mathrm{s}, \mathrm{t})=$ Koordinat Centroid

4. Kelompokkan objek berdasarkan jarak ke Centroid terdekat

5. Ulangi langkah ke-2, lakukan iterasi hingga Centroid bernilai optimal

\section{HASIL DAN PEMBAHASAN}

\section{A. Perhitungan Dengan Algoritma K-Means}

Pengelompokan data dilakukan dengan menggunakan $K$ Means Clustering dengan sampel data jumlah penduduk setiap kelurahan. Untuk mendapatkan hasil dari penelitian dilakukan perhitungan manual untuk proses Clustering menggunakan algoritma K-Means. Proses Clustering dilakukan mulai dari penentuan data yang ingin di Cluster. Berikut adalah data sampel.

TABEL 1. DATA JUMLAH PENDUDUK

\begin{tabular}{|c|c|c|c|c|c|c|}
\hline 13 & Sipinggol Pinggol & 4,578 & 4,617 & 4,656 & 4,689 & 4,735 \\
\hline 14 & Banjar & 5220 & 5,264 & 5,313 & 5,362 & 5,408 \\
\hline 15 & Teladan & 2,452 & 2,473 & 2,498 & 2,522 & 2,545 \\
\hline 16 & Kebun Sayur & 4,248 & 4,283 & 4310 & 4,336 & 4,358 \\
\hline 17 & Tomuan & 9,575 & 9,656 & 9,718 & 9,779 & 9,832 \\
\hline 18 & Pahlawan & 2,628 & 2,651 & 2,692 & 2,734 & 2,775 \\
\hline 19 & Asuhan & 4,949 & 4,991 & 5,019 & 5,047 & 5,072 \\
\hline 20 & Merdeka & 3,508 & 3,537 & 3,557 & 3,577 & 3,594 \\
\hline 21 & Pardomuan & 4,412 & 4,449 & 4,474 & 4,499 & 4520 \\
\hline 22 & Siopat Suhu & 10,882 & 10,975 & 11,041 & 11,107 & 11,165 \\
\hline 23 & Toba & 2,266 & 2,286 & 2,302 & 2,318 & 2,333 \\
\hline 24 & Karo & 3,387 & 3,415 & 3,436 & 3,457 & 3,475 \\
\hline 25 & Simalungun & 2,543 & 2,565 & 2,581 & 2,596 & 2,609 \\
\hline 26 & Martimbang & 3,616 & 3,646 & 3,668 & 3690 & 3,709 \\
\hline 27 & Kristen & 2220 & 2,238 & 2,254 & 2270 & 2,284 \\
\hline 28 & Aek Nauli & 3,827 & 3860 & 3,884 & 3,908 & 3,929 \\
\hline 29 & Melayu & 7650 & 7,715 & 7,769 & 7,822 & 7870 \\
\hline 30 & Martoba & 9,148 & 9,226 & 9,287 & 9,348 & 9,453 \\
\hline 31 & Baru & 6,099 & 6,150 & 6,191 & 6,231 & 6,267 \\
\hline 32 & Sukadame & 5,394 & 5440 & 5,476 & 5,511 & 5,542 \\
\hline 33 & Kahean & 7,312 & 7,374 & 7,421 & 7,467 & 7,508 \\
\hline 34 & Sigulang Gulang & 6,228 & 6280 & 6,322 & 6,363 & 6400 \\
\hline 35 & Bane & 6,708 & 6,765 & 6,811 & 6,856 & 6,896 \\
\hline 36 & Sumber Jaya & 5,773 & 5,821 & 5,858 & 5,894 & 5,926 \\
\hline 37 & Tambun Nabolon & 6140 & 6,192 & 6,265 & 6320 & 6,38 \\
\hline 38 & Tanjung Tongah & 3,277 & 3,305 & 3,339 & 3,373 & 3,405 \\
\hline 39 & Pondok Sayur & 6,065 & 6,117 & 6,164 & 6210 & 6,252 \\
\hline 40 & Tanjung Pinggir & 4,636 & 4,675 & 4,711 & 4,746 & 4,777 \\
\hline 41 & Naga Pita & 10,026 & 10,112 & 10,191 & 10,268 & 10,339 \\
\hline 42 & Naga Pitu & 4,549 & 4,587 & 4,662 & 4,657 & 4,689 \\
\hline 43 & Gurilla & 1,981 & 1,981 & 2,021 & 2,026 & 2,039 \\
\hline 44 & Setia Negara & 7,241 & 7,241 & 7,399 & 7,496 & 7,589 \\
\hline 45 & Bah Kapul & 9,772 & 9,772 & 9,936 & 10,016 & 10,089 \\
\hline 46 & Bah Sorma & 3360 & 3360 & 3,426 & 3,464 & 3500 \\
\hline 47 & Bukit Shofa & 6,163 & 6,163 & 6,256 & 6,296 & 6,331 \\
\hline 48 & Simarimbun & 2,246 & 2,265 & 2,286 & 2,307 & 2,326 \\
\hline 49 & Tong Marimbun & 3,096 & 2,198 & 2,219 & 2240 & 3,218 \\
\hline 50 & Nagahuta & 3,045 & 3,121 & 3,154 & 3,187 & 3,157 \\
\hline 51 & Nagahuta Timur & 2,179 & 2,116 & 2,139 & 2,162 & 2260 \\
\hline 52 & Pematang Marihat & 2,098 & 3,071 & 3,101 & 3130 & 2,183 \\
\hline 53 & Marihat Jaya & 2,943 & 2,968 & 2,998 & 3,027 & 3,054 \\
\hline
\end{tabular}

\begin{tabular}{|c|c|c|c|c|c|c|}
\hline \multirow{2}{*}{ No } & \multirow{2}{*}{ Kelurahan } & \multicolumn{5}{|c|}{ Jumlah Penduduk } \\
\cline { 3 - 7 } & \multirow{2}{*}{ Pardamean } & 3,536 & 3,484 & 3,651 & 3,557 & 3,589 \\
\hline 2 & Parhorasan Nauli & 3,054 & 3,011 & 3,965 & 3,073 & 3,102 \\
\hline 3 & Sukamaju & 3,868 & 3,827 & 3,859 & 3,893 & 3,928 \\
\hline 4 & Sukamakmur & 1,747 & 1,742 & 3,521 & 1,777 & 1,794 \\
\hline 5 & Sukaraja & 2,663 & 2,624 & 2760 & 2,678 & 2,703 \\
\hline 6 & BP Nauli & 2340 & 2,935 & 3,042 & 2,995 & 3,022 \\
\hline 7 & Mekar Nauli & 1,888 & 1,634 & 1,651 & 1,669 & 1,684 \\
\hline 8 & Dwi Kora & 2,329 & 1,348 & 2,371 & 2,393 & 2,414 \\
\hline 9 & Proklamasi & 1640 & 1,654 & 1,672 & 1690 & 1,707 \\
\hline 10 & Bantan & 11,114 & 11,209 & 11,308 & 11,406 & 11,496 \\
\hline 11 & Timbang Galung & 3,237 & 3,264 & 3,294 & 3,323 & 3,35 \\
\hline 12 & Simarito & 6,555 & 6610 & 6670 & 6,729 & 6,785 \\
\hline
\end{tabular}


1. Menentukan Jumlah k Cluster, Pada tahap ini dapat diketahui:

Jumlah Cluster: 3

Jumlah Data: 53

2. Menentukan Centroid awal secara random, penentuan pusat Cluster awal ditentukan secara random yang diambil dari data yang ada dalam range.

TABEL 2. CENTROID DATA AWAL

\begin{tabular}{|c|c|c|c|c|c|}
\hline Kelurahan Gurilla & 1,981 & 1,981 & 2,021 & 2,026 & 2,039 \\
\hline Kelurahan Baru & 6,099 & 6,150 & 6,191 & 6,231 & 6,267 \\
\hline Kelurahan Bantan & 11,114 & 11,209 & 11,308 & 11,406 & 11,496 \\
\hline
\end{tabular}

3. Menghitung Centroid terdekat, berikut adalah contoh perhitungan jumlah penduduk dengan algoritma $K$ Means:

Kel. Pardamean

$\operatorname{Data}(1,1)=$ $\sqrt{\frac{(3,536-1,981)^{2}+(3,484-1,981)^{2}+(3,651-2,021)^{2}+}{(3,557-2,026)^{2}+(3,589-2,039)^{2}}}=3,475686$

$\operatorname{Data}(1,2)=$

$\sqrt{(3,536-6,099)^{2}+(3,484-6,150)^{2}+(3,651-6,191)^{2}+}=5,869419$

$\sqrt{(3,557-6,231)^{2}+(3,589-6,267)^{2}}$

$\operatorname{Data}(1,3)=$

$\sqrt{(3,536-11,114)^{2}+(3,484-11,209)^{2}+(3,651-11,308)^{2}+}=17,31643$

$\sqrt{(3,557-11,406)^{2}+(3,589-11,496)^{2}}$

Kel. Marihat Jaya

$\operatorname{Data}(53,1)=$

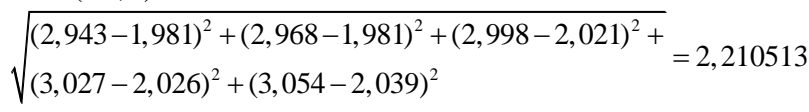

$\operatorname{Data}(53,2)=$

$(2,943-6,099)^{2}+(2,968-6,150)^{2}+(2,998-6,191)^{2}+$

$\sqrt{(3,027-6,231)^{2}+(3,054-6,267)^{2}}$

$=7,132299$

$\operatorname{Data}(53,3)=$

$\sqrt{\frac{(2,943-11,114)^{2}+(2,968-11,209)^{2}+(2,998-11,308)^{2}+}{(3,027-11,406)^{2}+(3,054-11,496)^{2}}}=18,57984$

Setelah semua data selesai dihitung, maka berikut ini adalah hasil dari perhitungan pada iterasi ke-1:

TABEL 3. HASIL PERHITUNGAN JARAK PUSAT CLUSTER ITERASI 1

\begin{tabular}{|c|l|l|l|l|l|}
\hline \multirow{2}{*}{ No } & \multirow{2}{*}{ Kelurahan } & \multicolumn{3}{|c|}{ Jarak Ke Centroid } & \multirow{2}{*}{ Jarak } \\
\cline { 3 - 5 } & Cluster1 & Cluster 2 & Cluster 3 & Terdekat \\
\hline 1 & Pardamean & 3,475686 & 5,869419 & 17,31643 & 3,475686 \\
\hline 2 & $\begin{array}{l}\text { Parhorasan } \\
\text { Nauli }\end{array}$ & 2,866626 & 6,63857 & 18,05515 & 2,866626 \\
\hline 3 & Sukamaju & 4,171419 & 5,171951 & 16,61944 & 4,171419 \\
\hline 4 & Sukamakmur & 1,57604 & 9,238242 & 20,61186 & 1,57604 \\
\hline 5 & Sukaraja & 1,513504 & 7,831758 & 19,27913 & 1,513504 \\
\hline 6 & BP Nauli & 1,996669 & 7,442058 & 18,87651 & 1,996669 \\
\hline
\end{tabular}

\begin{tabular}{|c|c|c|c|c|c|}
\hline 7 & Mekar Nauli & 0,720716 & 10,02767 & 21,47421 & 0,720716 \\
\hline 8 & Dwi Kora & 0,958961 & 9,024431 & 20,44511 & 0,958961 \\
\hline 9 & Proklamasi & 0,753745 & 10,09615 & 21,54373 & 0,753745 \\
\hline 10 & Bantan & 20,79027 & 11,44773 & 0 & 0 \\
\hline 11 & $\begin{array}{l}\text { Timbang } \\
\text { Galung }\end{array}$ & 2,871425 & 6,471322 & 17,91889 & 2,871425 \\
\hline 12 & Simarito & 10,42137 & 1,079493 & 10,3689 & 1,079493 \\
\hline 13 & $\begin{array}{l}\text { Sipinggol } \\
\text { Pinggol }\end{array}$ & 5,915751 & 3,427031 & 14,87454 & 3,427031 \\
\hline 14 & Banjar & 7,388202 & 1,954882 & 13,40209 & 1,954882 \\
\hline 15 & Teladan & 1,092468 & 8,250403 & 19,69797 & 1,092468 \\
\hline 16 & Kebun Sayur & 5,137302 & 4,205396 & 15,65309 & 4,205396 \\
\hline 17 & Tomuan & 17,22377 & 7,881108 & 3,567135 & 3,567135 \\
\hline 18 & Pahlawan & 1,53646 & 7,807491 & 19,25478 & 1,53646 \\
\hline 19 & Asuhan & 6,721805 & 2,620925 & 14,06865 & 2,620925 \\
\hline 20 & Merdeka & 3,454821 & 5,887924 & 17,33562 & 3,454821 \\
\hline 21 & Pardomuan & 5,503552 & 3,839179 & 15,2869 & 3,839179 \\
\hline 22 & Siopat Suhu & 20,17991 & 10,83725 & 0,615492 & 0,615492 \\
\hline 23 & Toba & 0,651852 & 8,691066 & 20,1387 & 0,651852 \\
\hline 24 & Karo & 3,185165 & 6,157559 & 17,60524 & 3,185165 \\
\hline 25 & Simalungun & 1,27291 & 8,069923 & 19,51759 & 1,27291 \\
\hline 26 & Martimbang & 3,703492 & 5,639227 & 17,08691 & 3,703492 \\
\hline 27 & Kristen & 0,544995 & 8,797964 & 20,2456 & 0,544995 \\
\hline 28 & Aek Nauli & 4,186066 & 5,156637 & 16,60432 & 4,186066 \\
\hline 29 & Melayu & 12,87051 & 3,527861 & 7,919898 & 3,527861 \\
\hline 30 & Martoba & 16,28588 & 6,943319 & 4,504564 & 4,504564 \\
\hline 31 & Baru & 9,342665 & 0 & 11,44773 & 0 \\
\hline 32 & Sukadame & 7,743805 & 1,598867 & 13,04658 & 1,598867 \\
\hline 33 & Kahean & 12,09043 & 2,747767 & 8,700061 & 2,747767 \\
\hline 34 & $\begin{array}{l}\text { Sigulang } \\
\text { Gulang }\end{array}$ & 9,635606 & 0,292942 & 11,15479 & 0,292942 \\
\hline 35 & Bane & 10,72822 & 1,385558 & 10,06218 & 1,385558 \\
\hline 36 & Sumber Jaya & 8,597536 & 0,745155 & 12,19288 & 0,745155 \\
\hline 37 & $\begin{array}{l}\text { Tambun } \\
\text { Nabolon }\end{array}$ & 9,503897 & 0,172078 & 11,28644 & 0,172078 \\
\hline 38 & Tanjung Tongah & 2,974909 & 6,367953 & 17,81545 & 2,974909 \\
\hline 39 & Pondok Sayur & 9,284677 & 0,060332 & 11,50563 & 0,060332 \\
\hline 40 & Tanjung Pinggir & 6,036373 & 3,306315 & 14,75394 & 3,306315 \\
\hline 41 & Naga Pita & 18,28673 & 8,944122 & 2,503704 & 2,503704 \\
\hline 42 & Naga Pitu & 5,857081 & 3,48581 & 14,93331 & 3,48581 \\
\hline 43 & Gurilla & 0 & 9,342665 & 20,79027 & 0 \\
\hline 44 & Setia Negara & 12,04083 & 2,702151 & 8,750896 & 2,702151 \\
\hline 45 & Bah Kapul & 17,68302 & 8,340788 & 3,108065 & 3,108065 \\
\hline 46 & Bah Sorma & 3,159062 & 6,184175 & 17,63147 & 3,159062 \\
\hline 47 & Bukit Shofa & 9,464018 & 0,129657 & 11,32637 & 0,129657 \\
\hline
\end{tabular}




\begin{tabular}{|l|l|l|l|l|l|}
\hline 48 & Simarimbun & 0,618414 & 8,724512 & 20,1721 & 0,618414 \\
\hline 49 & Tong Marimbun & 1,662936 & 8,101702 & 19,50993 & 1,662936 \\
\hline 50 & Nagahuta & 2,512614 & 6,831044 & 18,27849 & 2,512614 \\
\hline 51 & Nagahuta Timur & 0,372411 & 8,981708 & 20,42897 & 0,372411 \\
\hline 52 & $\begin{array}{l}\text { Pematang } \\
\text { Marihat }\end{array}$ & 1,899405 & 7,831449 & 19,23783 & 1,899405 \\
\hline 53 & Marihat Jaya & 2,210513 & 7,132299 & 18,57984 & 2,210513 \\
\hline
\end{tabular}

4. Menghitung Centroid baru untuk iterasi berikutnya dengan menghitung rata-rata nilai pada masing-masing Cluster. Berikut ini adalah perhitungan Centroid baru pada masing-masing Cluster:

$\mathrm{C}_{1}=$

$3,536+3,054+3,868+1,747+2,663+2,340+$

$1,888+2,329+1,640+3,237+2,452+2,628+$

$3,508+2,266+3,387+2,543+3,616+2,220+$

$3,827+3,277+1,981+3,360+2,246+3,096+$

$3,045+2,179+2,098+2,943$ $=2,749071$

$\mathrm{C}_{1}=$

$3,484+3,011+3,827+1,742+2,624+2,935+$

$1,634+1,348+1,654+3,264+2,473+2,651+$

$3,537+2,286+3,415+2,565+3,646+2,238+$

$3,860+3,305+1,981+3,360+2,265+2,198+$

$3,121+2,116+3,071+2,968$ $=2,734964$

$\mathrm{C}_{1}=$

$3,651+3,965+3,859+3,521+2,760+3,042+$

$1,651+2,371+1,672+3,294+2,498+2,692+$

$3,557+2,302+3,436+2,581+3,668+2,254+$

$3,884+3,339+2,021+3,426+2,286+2,219+$

$\underline{3,154+2,139+3,101+2,998}$

$$
28=2,905036
$$

Jika tahapan iterasi telah mencapai hasil yang sama tanpa dan tidak mengalami perubahan lagi, maka perhitungan dihentikan.

Pada penelitian ini perhitungan dilakukan sampai iterasi ke-3. Setelah perhitungan selesai dilakukan sampai iterasi ke 3 dan telah dikelompokkan, maka hasil akhir posisi Cluster dari Centroid iterasi ke 3 dapat dilihat pada tabel dibawah ini:

TABEL 4. HASIL PENGELOMPOKAN ITERASI KE 3

\begin{tabular}{|c|l|c|}
\hline Cluster & \multicolumn{1}{|c|}{ Kelurahan } & Jumlah \\
\hline C1 & Pardamean, Parhorasan Nauli, Sukamaju, & \\
& Sukamakmur, Sukaraja, BP Nauli, Mekar Nauli, & \\
& Dwi Kora, Proklamasi, Timbang Galung, & \\
& Teladan, Kebun Sayur, Pahlawan, Merdeka, & \multirow{2}{*}{29} \\
& Toba, Karo, Simalungun, Martimbang, Kristen, & \\
& Aek Nauli, Tanjung Tongah, Gurilla, Bah Sorma, & \\
& Simarimbun, Tong Marimbun, Nagahuta, & \\
& Nagahuta Timur, Pematang Marihat, Marihat & \\
\hline C2 & Jaya. & \\
& Simarito, Sipinggol Pinggol, Banjar, Asuhan, & \multirow{2}{*}{18} \\
\hline
\end{tabular}

\begin{tabular}{|c|l|c|}
\hline & $\begin{array}{l}\text { Sigulang Gulang, Bane, Sumber Jaya, Tambun } \\
\text { Nabolon, Pondok Sayur, Tanjung Pinggir, Naga } \\
\text { Pitu, Setia Negara, Bukit Shofa. }\end{array}$ & \\
\hline C3 & $\begin{array}{l}\text { Bantan, Tomuan, Siopat Suhu, Martoba, Naga } \\
\text { Pita, Bah Kapul. }\end{array}$ & 6 \\
\hline
\end{tabular}

\section{B. Implementasi Pada Aplikasi RapidMiner}

Dalam Pengimplementasian pada aplikasi RapidMiner dapat dilihat sebagai berikut:

1. Import Data kedalam RapidMiner dalam bentuk Sheet Excel

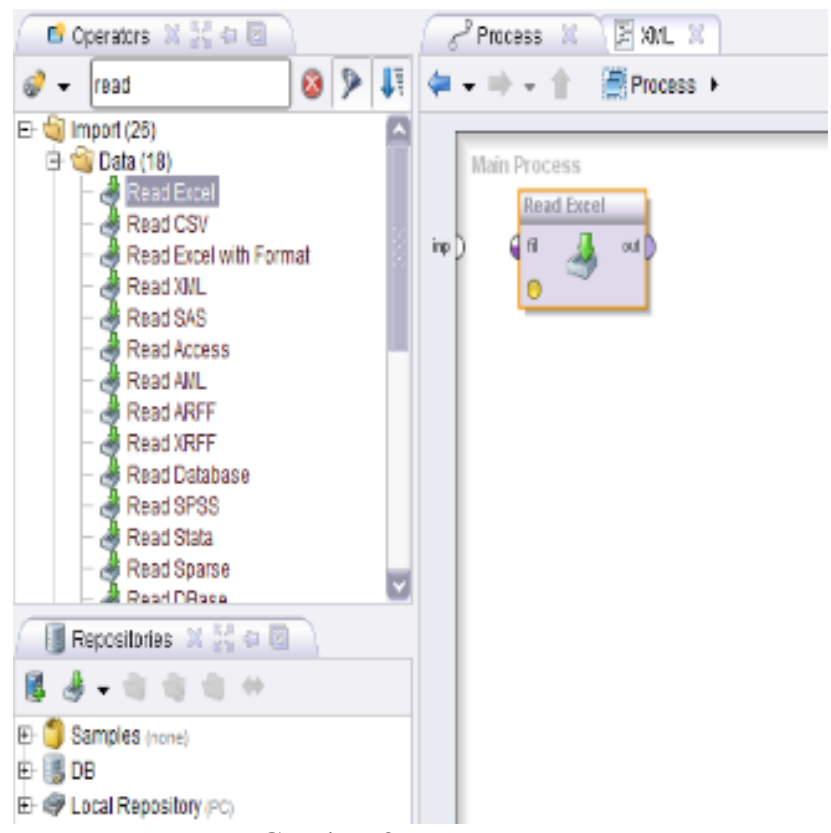

Gambar 3. Import Data

2. Import Configuration Wizard

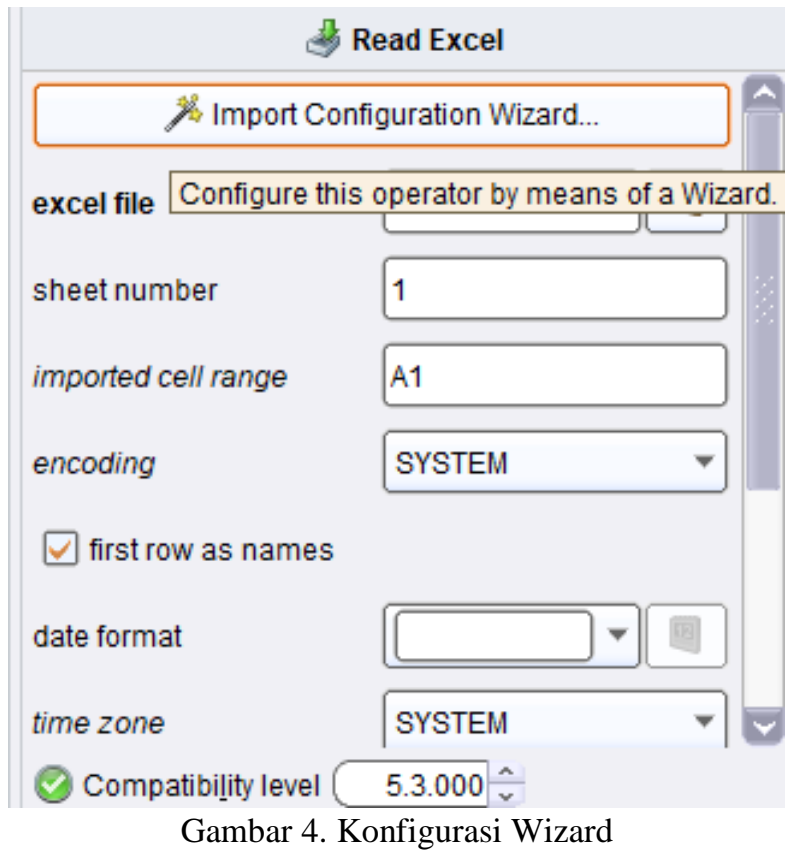


3. Setelah Configuration Wizard Pilih file, sesuaikan Atribut dan Tipe Data

\begin{tabular}{|c|c|c|c|c|c|}
\hline \multicolumn{2}{|c|}{ Reload data } & \multicolumn{2}{|c|}{ (?) Guess value types } & \multicolumn{2}{|c|}{$\square$ Preview uses only first 100 row } \\
\hline$\square$ & 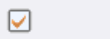 & $\square$ & $\square$ & $\square$ & $\square$ \\
\hline Kelurahan & 2015.0 & 2016.0 & 2017.0 & 2018.0 & 2019.0 \\
\hline polyno... $>$ & integer $>$ & integer $>$ & integer $>$ & integer $>$ & integer $>$ \\
\hline id & attribute $>$ & attribute - & attribute $=$ & attribute $=$ & attribute - \\
\hline Kelurahan $\mathrm{P}$ & 3536 & 3484 & 3651 & 3557 & 3589 \\
\hline Kelurahan $\mathrm{P}$ & 3054 & 3011 & 3965 & 3073 & 3102 \\
\hline Kelurahan S & 3868 & 3827 & 3859 & 3893 & 3928 \\
\hline Kelurahan S & 1747 & 1742 & 3521 & 1777 & 1794 \\
\hline Kelurahan $\mathrm{S}$ & 2663 & 2624 & 2760 & 2678 & 2703 \\
\hline Kelurahan B & 2340 & 2935 & 3042 & 2995 & 3022 \\
\hline Kelurahan M 1 & 1888 & 1634 & 1651 & 1669 & 1684 \\
\hline Kelurahan D & 2329 & 1348 & 2371 & 2393 & 2414 \\
\hline Kelurahan $\mathrm{P}$ & 1640 & 1654 & 1672 & 1690 & 1707 \\
\hline Kelurahan B & 11114 & 11209 & 11308 & 11406 & 11496 \\
\hline Kelurahan $\mathrm{T}$ & 3237 & 3264 & 3294 & 3323 & 3350 \\
\hline Kalueahane & sece & esan & segn & e7nn & $\varepsilon 70=$ \\
\hline \multicolumn{6}{|l|}{0 errors. } \\
\hline \multicolumn{4}{|c|}{ Row, Column } & \multicolumn{2}{|c|}{ Error } \\
\hline
\end{tabular}

Gambar 5. Penyesesuai Atribut dan Tipe Data

4. Menambahkan Model K-Means

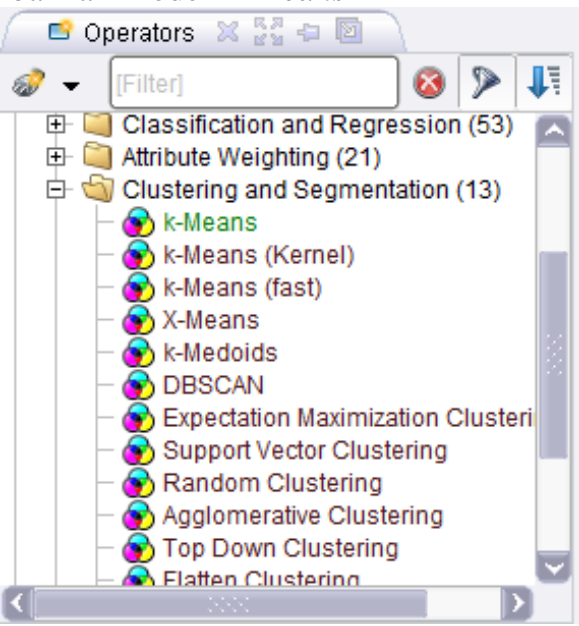

Gambar 6. Import Model K-Means

5. Pemprosesan Sistem RapidMiner

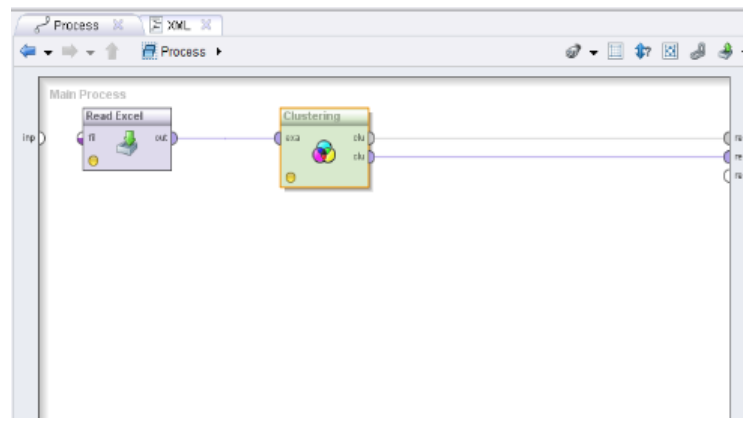

Gambar 7. Pemprosesan Data
6. Hasil Pengelompokan dalam RapidMiner

Tampilan Text View

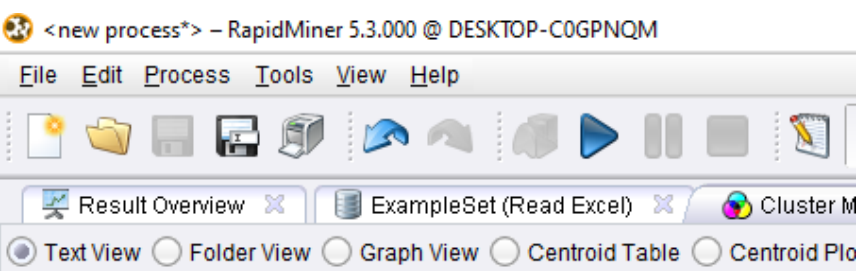

\section{Cluster Model}

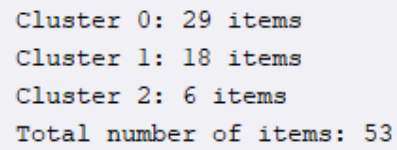

Gambar 8. Hasil Tampilan Text View

\section{Tampilan Plot View}

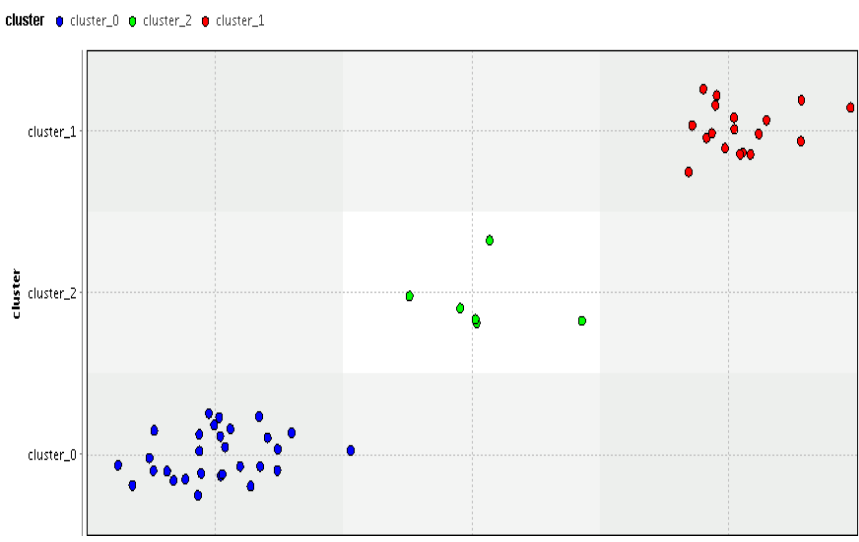

Gambar 9. Hasil Tampilan Plot View

Setelah melakukan implementasi menggunakan aplikasi RapidMiner, maka hasil yang didapat dari implementasi RapidMiner sama dengan hasil dari perhitungan manual $K$ Means.

\section{KESIMPULAN}

Berdasarkan pembahasan dan hasil implementasi software RapidMiner pada pengelompokan jumlah penduduk berdasarkan kelurahan, maka dapat disimpulkan sebagai berikut: Penerapan data mining dengan algoritma $K$-Means dapat diterapkan, dan sumber data yang digunakan pada penelitian ini adalah dari BPS kota Pematangsiantar dengan subjek data jumlah penduduk berdasarkan kelurahan (20152019). Jumlah record yang digunakan sebanyak 53 kelurahan dengan menghasilkan 3 Cluster yaitu Cluster rendah sebanyak 29 kelurahan yaitu Pardamean, Parhorasan Nauli, Sukamaju, Sukamakmur, Sukaraja, BP Nauli, Mekar Nauli, Dwi Kora, Proklamasi, Timbang Galung, Teladan, Kebun Sayur, Pahlawan, Merdeka, Toba, Karo, Simalungun, Martimbang, Kristen, Aek Nauli, Tanjung Tongah, Gurilla, Bah Sorma, Simarimbun, Tong Marimbun, Nagahuta, Nagahuta Timur, Pematang Marihat, Marihat Jaya. Dan Cluster sedang 
sebanyak 18 kelurahan yaitu Simarito, Sipinggol Pinggol, Banjar, Asuhan, Pardomuan, Melayu, Baru, Sukadame, Kahean, Sigulang Gulang, Bane, Sumber Jaya, Tambun Nabolon, Pondok Sayur, Tanjung Pinggir, Naga Pitu, Setia Negara, Bukit Shofa. Sedangkan Cluster tinggi sebanyak 6 kelurahan yaitu Bantan, Tomuan, Siopat Suhu, Martoba, Naga Pita, Bah Kapul.

Berdasarkan hasil pengujian $K$-Means untuk kasus jumlah penduduk menggunakan Tools RapidMiner versi 5.3 diperoleh hasil yang sama dengan analisis perhitungan algoritma K-Means.

\section{UCAPAN TERIMA KASIH}

Puji dan syukur penulis ucapkan kepada Tuhan yang Maha Esa, karena Berkat dan Kasih-Nya penulis dapat menyelesaikan penelitian ini. Penulis mengucapkan terima kasih kepada STIKOM Tunas Bangsa serta Bapak Indra Gunawan dan Ibu Ika Purnamasari selaku pembimbing atas izin dan dukungan dalam proses penelitian ini. Serta penulis mengucapkan terima kasih kepada Orang tua, keluarga, dan sahabat atas doa, kasih sayang, nasihat, semangat dan dukungan kepada penulis.

\section{REFERENSI}

[1] B. P. Statistik and K. Pematangsiantar, Katalog: 4102002.1273. 2017.

[2] S. Ashari, S. Khansa, C. H. M. Surudin, and I. N. Isnainiyah, "KLUSTERING JUMLAH PENDUDUK KOTA BANDUNG BERDASARKAN JENIS KELAMIN PER KECAMATAN PADA TAHUN 2012 DENGAN METODE K-MEANS," Semin. Nas. Inform. Sist. Inf. Dan Keamanan Siber, pp. 22-28, 2018.

[3] S. Sonang, A. T. Purba, and F. O. I. Pardede, "Pengelompokan Jumlah Penduduk Berdasarkan Kategori Usia Dengan Metode K-Means," $J$.
Tek. Inf. dan Komput., vol. 2, no. 2, pp. 166-172, 2019, doi: 10.37600/tekinkom.v2i2.115.

[4] R. W. Nasution, Suhada, I. O. Kirana, I. Gunawan, and I. P. Sari, "Penerapan Data Mining Untuk Pengelompokan Minat Konsumen Terhadap Pengguna Jasa Pengiriman Pada PT . Jalur Nugraha Ekakurir ( JNE ) Pematangsiantar," RESOLUSI Rekayasa Tek. Inform. dan Inf., vol. 1, no. 4, pp. 274-281, 2021.

[5] D. W. Sitohang and A. Rikki, "Implementasi Algoritma K- Means Clustering untuk Mengelompokkan Data Gizi Balita pada Kecamatan Garoga Tapanuli Utara," KAKIFIKOM (KUMPULAN Artik. KARYA Ilm. Fak. ILMU Komput. -, vol. 1, no. 2, pp. 80-92, 2019.

[6] K. Fatmawati and A. P. Windarto, "Data Mining: Penerapan Rapidminer Dengan K-Means Cluster Pada Daerah Terjangkit Demam Berdarah Dengue (Dbd) Berdasarkan Provinsi," CESS (Journal Comput. Eng. Syst. Sci., vol. 3, no. 2, pp. 173-178, 2018, doi: 10.24114/cess.v3i2.9661.

[7] K. F. Irnanda, A. P. Windarto, I. S. Damanik, and I. Gunawan, "Penerapan K-Means pada Proporsi Individu dengan Keterampilan (Teknologi Informasi dan Komunikasi) TIK Menurut Wilayah," Semin. Nas. Sains Teknol. Inf., no. c, pp. 452-456, 2019.

[8] Y. R. Sari, A. Sudewa, D. A. Lestari, and T. I. Jaya, "Penerapan Algoritma K-Means Untuk Clustering Data Kemiskinan Provinsi Banten Menggunakan Rapidminer," CESS (Journal Comput. Eng. Syst. Sci., vol. 5, no. 2, pp. 192-198, 2020, doi: 10.24114/cess.v5i2.18519.

[9] D. Gultom, H. Dame Tampubolon, L. Yolanda Hutabarat, F. R. Ilmi H Zer, and D. Hartama, "Penerapan Algoritma K-Means Untuk Mengetahui Tingkat Tindak Kejahatan Daerah Pematangsiantar," $J$. Teknol. Inf., vol. 4, no. 1, pp. 146-151, 2020.

[10] R. A. Margolang, S. R. Andani, and M. R. Lubis, "Implementasi Data Mining dalam Mengelompokkan Rumah Tangga Kumuh di Perkotaan Berdasarkan Provinsi Menggunakan Algoritma K-Means," Pros. Semin. Nas. Ris. Inf. Sci., vol. 1, no. September, pp. 602-609, 2019, doi: 10.30645/senaris.v1i0.66 